\title{
Teaching a Second Language
}

\section{to Young Learners}

\section{A Theoretical Approach}

DOI: $10.47050 / 66515321.280-301$

Jenny Johana Izquierdo Casadiego, Olesya Parakhina

Every year, more people are aware of the importance of being multilingual. Early childhood is the best period for language acquisition. There are four language skills: speaking, listening, reading, and writing. When a preschooler is learning a second language, the objective is to improve these skills along with developing the child's personality.

The "best" programme for teaching second languages to young learners is still an open question, however. The current theoretical approach will expose some methods that modern educators use to introduce preschool children to a second language.

A multisensory approach is supported in the theory of multiple intelligence and learning styles. This approach proposes teaching children through their individual learning styles, such as auditory, visual, tactile, and kinesthetic. The multisensory approach to teaching preschoolers a second language recognizes that every child is capable of learning, allowing every individual to acquire knowledge according to their characteristics.

\section{Keywords:}

learning styles

multisensory approach

preschoolers

second language

young learners 


\section{Introduction}

Language is a natural skill of a person - it allows us to express our needs and emotions or transfer culture and traditions to new generations. Starting to learn a second language at an early age is one of the most essential abilities as all cognitive resources are available for it (Diez, 2010). In the early years, the brain is predisposed to new knowledge; with the right approach, a child can manage different languages because the brain can generate more neural connections for them. According to Montessori and Bofill (1986), the mind of a child can absorb language from their environment. If a preschooler has access to different languages in the natural environment, they will absorb them.

While a child is learning a native language, they can also learn and understand a second and even a third one at the same time (Montessori $\&$ Vera, 1918). The sensitive period in which children are at the preschool age is the right time for gaining experience in a second language. Sensitive periods are defined by Montessori and Vera as "windows of opportunity", allowing children to develop deeply in a certain field of knowledge. Learning vocabulary is easy for them, and adults can give a child natural access to these possibilities of knowledge.

According to Lomakina and Laer (2014), preschoolers in an English class should have interest in the new language. They should not feel stressed or discomforted. The teacher, parents and a speech therapist should decide if a preschooler is ready to learn a new language and determine how they feel during the lesson time, i.e. whether they are developing or if some kind of stress is being generated.

Creating a motivational environment for children allows them to develop interest in a second language, and using different strategies and programmes lets a preschooler feel that another language is something natural, fun, interesting and enjoyable. As such, the use of music and games is recommended. Using rhymes is favorable for creating an excellent psychological climate and reducing psychological stress, as it increases the emotional tone and keeps children interested in learning a second language. It is possible to use them as relaxation or physical activities at any stage of a lesson when children need a discharge that relieves stress and restores their ability to work (Chakhchakhova, Tolstykh \& Ansimova, 2016).

International experts (e.g. Diez, 2010; Medina, Melo \& Palacios, 2010; Polo Torres, 2005) argue that the best age to start to learn languages 
is preschool age. According to these findings, children can recognize different languages and "use" a second language alongside their own. The scientific explanation for this phenomenon is that in the first years of a child's life, the neural connections of the brain are only beginning to develop and the vocal cords are adjusting to tune and strengthening in order to produce any sound; consequently, a child can speak any language naturally.

Russian experts, e.g. Sholpo (1999), Koryakovtseva (2010), Lomakina and Laer (2014) and Vorobyeva (2011), have also pointed out the positive impact of English on developing a preschooler's personality. Doctor of Education Milrud (2014) authored the "English to school" manual, used for teaching English to the children of the preschool age, to promote children's intellectual development, accelerate their speech development and form essential elements of social competence. Learning English helps their early integration into the multicultural space of the modern world, reinforces their communicative skills in interactions with teachers, parents, and classmates, trains universal cognitive activities, and prepares them for their school education (Lomakina \& Laer, 2014).

What method will help the child learn a second language is still an open question. Various methods and approaches have been developed related to teaching second languages to children. Since getting into the deep world of a language is a long-term process, motivation and interest are crucial to continuing this development.

\section{Language acquisition}

The language acquisition occurs spontaneously. In their interaction with their social environment, a child absorbs words and sounds, which are later associated with objects, feelings, and situations. The study of language development must take into account that learning to speak is not only learning how to pronounce and combine sounds but also how to use words and understand how they get a meaning in a particular context.

According to Montessori and Bofill (1986), the study of language in infancy is a natural process during which the brain absorbs information, which allows children to learn knowledge about the world around them. In a natural and healthy environment, the child listens to sounds that will later become words and sentences with meaning. Over time, this 
information makes sense, and the classification of actions, objects, feelings, and abstract concepts occurs. Afterward, the child naturally understands how the language works and, thus, can use all aspects of the language, such as grammar rules, phonetics, pronunciation, etc. (Lněničková \& Chocholatá, 2015).

Behaviourism, as a psychological theory, affirms that language has a function in the child's environment, and as this language is reinforced by their environment, the child must use it as a communication tool. According to Skinner (1957), a person develops language through associations; the child correlates the object that they see with the word that they hear. The environment contributes to this by allowing the child to satisfy their needs through language. Vygotsky claimed that language develops in interaction with its environment and for a communicative purpose (López Maján, 2018).

Chomsky says that the ability to acquire a language is innate, meaning that the human being is born with the ability to understand and acquire any language. This ability is called universal grammar, which is a set of rules that all the languages in the world share and which allows them to be learnt in a short period of time by a child, since they were born with the ability to understand these rules and assimilate them.

\section{Cognitive Theory}

Cognitive theories declare that the development of language is the result of previous cognitive development. In other words, cognitive development is responsible for language development. This theory is represented by several authors who have various positions:

1. For Vygotsky and the Russian school, language is the main element responsible for cognitive development (Oyarbide, 2004);

2. For Piaget and the Geneva school, language depends on learning and other competencies for its development (ibidem);

3. For Bruner and the Harvard school, language is the most powerful amplifier of human faculties and is considered the principal instrument in the cultural transmission of such faculties (ibidem). 
Piaget, being the most significant representative of cognitive development, defined language learning in four stages. For him, each stage is the result of the interaction between the maturity of the organism and the environment.

The first stage is from birth to 8 months, prior to the child's first words. The child tries to communicate through crying, gestures and the sounds of babbling unintentionally. The next period goes from 8 to 24 months, during which they increase their vocabulary to a range of 40-50 words and two-word phrases begin to appear (Piaget, 1981).

In the preconceptual stage of symbolism, which goes from the age of 18 months to 4 years, the child begins to give meaning to everything around them. Then there is the intuitive stage that goes from the age of 4 years to 7 and a half years. At this time, the child abandons symbolism and begins to understand reality; this presents improvements in their social behaviour. For example, they start using intuition to solve problems and begin to form more complex structures, e.g. verbal complements and relative and coordinated sentences (ibidem).

According to Vygotsky and his book Thought and Language (1934), a language is a decisive factor in the formation of mental processes. In order to analyze the higher psychological functions, it is necessary to investigate how the organisation of mental processes is influenced by language. Similarly to Piaget, he was interested in the effect of communication on the development of thought (Lucci, 2011).

Vygotsky pointed out that language has two functions: external communication with others and the regulation of internal thoughts. According to him, during the first years of life, a connection is generated between the thought and the language and together they mutually develop throughout one's lifetime (ibidem).

The preschool age (from 3 to 7 ) is characterised by improving pronunciation and phonemic perception, e.g. vocabulary increases and abstract speech and retelling skills appear. Children over the age of 7 continue to improve their grammar, writing and reading skills. This stage does not have strict age boundaries, as it is dependent not only on the environment but also on the individual child's mental constitution and personal characteristics (Tkachenko, 2016).

The acquisition of language requires the activation and development of interaction with the environment. Every child should 
be in an environment which contributes to their development and facilitates their language learning. Thus, interaction with more than one language does not interrupt the child from the full acquisition of their native language. The presence of two languages is in fact useful for the child because it allows the second language to develop naturally as well as the native one (Alvares, 2010).

Therefore, preschool education has a particularly significant role, during which time the child expands his/her world, meanings, vocabulary and linguistic structures with the all-new situations around them. It also creates the need in them to talk about different topics and explore diverse ways of using language. It is consequently interesting to teach second languages in preschool; the objective of these classes is to create an environment where a child can speak as freely they do in their native language.

\section{Language skills (listening, speaking, reading, writing)}

Language ability comprises four areas: writing, reading, speaking and listening. These are areas that a child develops in a healthy environment. However, when a person is studying a second or third language, developing abilities in these areas should be planned carefully by teachers, and it is necessary for them to prepare classes aimed at developing each of these language skills.

Listening: This is the first skill to be stimulated and developed. At the first moment of life, a child begins a lengthy period of "muteness", as Montessori illustrated in 1918, but the children are not just silent: they are listening actively to the sounds around them. Over time, this allows them to understand and start repeating familiar sounds. This is the first step in acquiring language (Lněničková \& Chocholatá, 2015).

At the first moment of hearing a language, it is normal not to distinguish one word from another and instead to perceive a continuous noise that seems meaningless. Every language has its own musicality; for example, some languages are low pitch and others are high pitch. This is why a person should have time for auditory adaptation to the segmental and suprasegmental characteristics of a new language, which are accent, rhythm, and intonation (Hernández, 2016).

Various nursery rhymes have been made for preschoolers that introduce the child to new languages in an interesting and natural 
way. Songs and poems are the main educational tools in the early childhood. Music, poems, rhymes, and songs allow children to improve their language skills (Martin, 2017). Rhymes are easier for the brain to remember; therefore, when teaching second languages, the use of nursery rhymes is an indispensable tool in every class.

With a good level of listening skill, a person should be able to perceive and understand the speech of the teacher and their classmates, understand the main content of uncomplicated authentic audio and video texts related to different communicative types of speech, and recognise context and significant and necessary information (Ageeva, 2018).

With preschoolers it is expected that they can understand rhymes, simple commands, routine words and phrases that a teacher uses every day, for example, if preschoolers are colouring it is expected a child is able to ask their groupmates to pass a particular colour in the second language.

Speaking: Speaking allows us to express feelings and thoughts. Speech and thought are interconnected. This is the basis for communication with our environment and the people around us. The main period of speech perception is from birth to 3 and a half years (Diez, 2010). Speech development in children is easier than in adults since their phonetic system is still developing. This enables the child to speak and repeat new vocabulary naturally, the same as a native speaker.

To develop this skill, the teacher needs to prepare activities that allow the child to be confident in talking, repeating, and expressing thoughts. Games and methods using dialogues and silences are useful for this purpose. The teacher can prepare games that encourage the children to verbally express simple questions and answers related to a proposed topic.

Reading: Reading is a complex skill. The task of the teacher is to associate the sounds with which the children are familiar with writing signs. When they can understand these, they have the power to provide information with meaning. Reading allows us to amplify our language not only in our reading, but also in our speaking, writing, and cognitive skills. By reading, people learn vocabulary, different grammatical components and concepts, and new information. 
A person with an appropriate level of reading skills in a language is supposed to read authentic texts of different genres and styles (Ageeva, 2018). At the preschool age, a child learns to associate sounds with graphic signs set for the native language, studies the letters of the alphabet, and builds words that indicate objects and situations around them. Reading is a process in which a child receives information from written characters (Ghaffari, Kashkouli \& Sadighi, 2017). In Russia, teachers traditionally wait until the child has a good knowledge of their own alphabet. When preschoolers aged 5-6 can read simple Russian phrases, they can start to learn other alphabets, for example the English one, then associate it with the related sounds.

Writing: The sensitive period for writing begins around the age of 3 and a half years and lasts up to the age of 4 and a half years. A 4-year-old child should be ready to write. This is the period of the formation and development of motility (Ghoneim \& Elghotmy, 2015). Writing serves as an additional means of communication besides speaking. At this point in life, the child learns to correlate words and concepts that they already know with a written representation.

Writing in kindergarten is a very sensitive subject. Children with a different alphabet in their mother language (as in Russia) could learn English letters by drawing them on paper. It is convenient for younger preschoolers (age 3-4) to stimulate fine motor skills with different hand activities, and with older preschoolers (age 5-6), it is possible to introduce writing in English. They can repeat what the teachers show them on a board or in a book, but it is important that the teachers monitor if the children understand what they are writing.

Different methods for the development of these communication skills have been searched for throughout the history and evolution of the educational technologies. Searching for the "right method" for teaching a second language has been the concern, historically, not only of teachers but also, and particularly, linguists, speech therapist and psychologists.

The work of these professionals in these years of methodological search allows us to know that this ideal method does not exist and will never exist. However, it is important to know the different methods that do exist in order to know the diversity of approaches that have been implemented through history and use and adapt the best of these to specific circumstances. 


\section{Second language teaching methods}

Language teaching distinguishes between general and specific, traditional and contemporary methods, and the literature has documented a number of methods and approaches designed to teach second languages. Some of the methods are grammar-translation, natural, conversational, direct, active, audio-lingual, audio-oral, situational, audiovisual, structural, suggestopedia and the method of silence, and the total physical response. Each method is distinguished by having its own approach, design and procedure for the activities for the promotion of language learning (Richards \& Rodgers, 2014).

\section{Grammar-Translation Method (GTM)}

As the name implies, this technique (the traditional form of language teaching, which dates back to the teaching of Latin and Greek) focuses on learning grammar and translation skills. It is based on learning a set of rules and grammatical exceptions that manifest themselves logically and are observable in written texts. Grammar learning is deducted, and the rules are presented, studied and practiced through translation exercises.

Although it is a frequently used method, its use is not recommended for preschool because it requires a basis for understanding the logic of the mother tongue, and children at this age have not yet deciphered this logic (Richards \& Rodgers, 2014).

The direct method

The direct method, developed by Maximiliano Berlitz and Gouin Francoise in the $19^{\text {th }}$ century, represented an improvement in the method of grammar-translation. This approach encourages direct connections between meanings and objects in the student's mother tongue and the second language without translation. Teachers and students use the second language exclusively in class, and the new material is demonstrated through actions or images (Richards \& Rodgers, 2014).

This method can be used in preschool, especially if the children are younger (age 3-4), since they are learning concepts. For older preschoolers, a little more care is required, especially if they are working in groups, since it may be stressful for them to be in the context where their mother tongue is not used as a linker with the second language. 
A natural approach

The foundations of this method were presented by Terrell and Krashen in 1983. For them, there is a clear difference between acquisition and learning. The main objective is the understanding of meanings. This method supports the theory that exposure and immersion in the target language are more important than the students' written production (Krashen, 1982). The acquisition theory on which this method is based is innatism, which gives the students a leading and highly active role. Grammar is reduced to a minimum (Sánchez, 2010).

This method has proven to be a big success in the kindergarten and schools (international schools) where children are immersed in a second language from the toddler age, where the aim is that all interactions with adults are in the second language. The child then grows with full access to this second language, obtaining as a consequence the total dominion of all the areas of language (writing, reading, speaking and listening).

For those who only have access to the second language in classes a couple of times a week, this method can be applied to generate the environment in which activities, such as games, manual activities, physical activities and others, allow natural interactions.

\section{Other approaches}

Nowadays, games, songs, and storytelling are frequently used in teaching languages. Moreover, in preschool education, the game method is the most actively used. At an early age, children love to play to develop their personality as well as their learning, cognitive, social, and motor skills. Games allow the child to improve physically, emotionally and mentally. By playing, the child is more involved in the proposed activities, and learning becomes more effective. The game should be a methodological component in language learning in kindergarten to help communication skills such as oral and written expression, comprehension and reading develop. In addition, playing creates an atmosphere where the child feels comfortable and motivated (Ghaffari, Kashkouli \& Sadighi, 2017).

The effectiveness of the game method has been shown by Madarsara, Youhanaee, Barati and Nasirahmadi (2015) in the research with Persian children who studied English as a second language. A group that studied with games remembered vocabulary better than the group where games 
were not used as a pedagogical strategy. It should be highlighted that the games should be used for a purpose; in teaching English as a second language, the game should be planned and oriented to teach a specific topic or study certain vocabulary. In places where a child is in a second language environment, it is also possible for them to play freely with some background music.

The total physical response (TPR) method proposed by Asher (2010) involves dance, mimic and dramatic movements of the body to learn vocabulary during lessons. According to Canga (2019), this teaching method is effective. He used it to teach English to children in Malaga and claims that this method contributes to learning the target language effectively.

The TPR method could be used for working with young children. The teacher should choose a series of children's songs that include simple acts and moves, and show them vocabulary in combination with these simple moves; as the result of these fun and interesting songs, children who join in and perform this physical activity can remember the words and link them when they are presented in other contexts (Martin, 2017).

The use of technology in teaching is becoming a necessity. For the study of second languages, parents and teachers use technology as a tool to help them in the learning process. Technological tools should only be considered as part of the learning method. Their use should be planned and focus on a specific goal. Even though it is possible to find apps, games, music, and videos for children and adults to learn languages on cell phones and computers (Gilakjani, 2012), language is based on human interaction, and this cannot be replaced with interactions with a machine. A child needs social relations to develop a language. On technological devices, the vocabulary is limited, and in human interactions, language is infinite.

The use of storytelling in preschool is a traditional method. Children love to listen to different stories, and this could also be used as a technique for learning a second language, e.g. reading stories with illustrations or other visual elements that are clear and full of color, in addition to providing a very pleasant moment for everyone. Children like to hear stories that are already familiar to them, so re-reading the stories repeatedly is fantastic for reviewing vocabulary and syntactic structures in a cozy and familiar environment. 
Apart from stimulating their imagination, reading in English allows children to develop the fundamental listening skills by hearing new words and grammatical structures.

Setyarini, Soleimani and Akbari (2011) used storytelling as a teaching technique. Their findings show that storytelling is a proper technique for teaching because preschoolers learnt English more enthusiastically. The preschoolers claim that this meant they could memorise the new vocabulary more easily. It also created a joyful atmosphere because the children were totally involved in it through listening, reading and creating their own story.

The craft (hand work) approach, also called manual work, requires a greater degree of mental work, since understanding must first be cultivated, then practical intelligence and, finally, skills must be acquired through construction and exercise. Imitation is both skillful and mechanical, but understanding of the activity is also needed. Crafts are commonly used in a preschool context, so involving them in second language classes could bring advantages for fine motor skills, cognitive and language development.

Crafts are beneficial from the points of view of both children and adults. Children love them because using crafts is usually a fun and relaxed activity for them, and at the same time they will be developing creativity and personal relationships, and they will undoubtedly reach a higher level in fine motor skills. The latter is related to the development of intelligence and memory and the reduction of stress (García \& Sanchez, 2013).

Crafts, of course, should be connected with the learning subject, and it is expected that they should be $90 \%$ completed by the child. The objective in a language class is not that the child has a beautiful craft to show to their parents, but that they can use the language while they are interacting, asking for paper with a certain colour, crayon, pencil, glue, etc. Also, the craft works to link the child with the rest of the activities. For example, a class could start with a song about animals, then proceed to some activity that involves acting like some animals, some storytelling about the animals, and end with a simple craft of an animal. Then the craft will be linked with the whole theme.

In accordance with the previously presented theoretical approaches, we want to propose a method that can be used to teach second languages to preschool children. This method uses a multisensory 
approach; consequently, it is necessary to be familiar with such concepts as: multisensory learning and teaching, the theory of multiple intelligences, and multisensory learning styles.

\section{Multisensory Learning and Teaching}

The concept of "multisensory" includes two words: "multi" from the Latin multum (many) and "sensory" from the Latin sensus (perception, feeling, sensation). According to this theory, people have diverse types of perception, thinking, and memory that could have certain sets of abilities: visual-spatial, musical-rhythmic, logical-mathematical, kinesthetic, naturalistic, linguistic, etc. This approach uses tasks that include music, sounds, songs, images, real objects, and motor activities. Regular change of tasks, focusing on different channels of perception, help to keep each preschooler involved during the lesson. By activating the senses, students develop the ability to concentrate, keep their attention, and keep language information in their long-term memory (Balashova, 2016).

Research by neuroscientists related to the field of education brings relevant conclusions about how the human brain processes and combines information. Thus, it is necessary to consider the natural predisposition or orientation of the brain to learn, which functions as a stimulator of learning processes (Jensen, 2004). This postulate emphasizes the relevance of developing meaningful educational practices based on what the student perceives as learning in interaction with their environment. It is important that learning takes place along multisensory paths, which provide an enabling environment for a diverse learning experience (Cañas \& Chacón, 2015).

In 1993, Howard Gardner put forward the theory of multiple intelligences. His work broadened the notion of what intelligence is. He believes that there are diverse types of intelligence. In training-teaching situations, according to Gardner, we often emphasise only verbal and linguistic intelligence. He suggests that people have a wide range of intelligence.

Gardner identifies eight types of intelligence: linguistic, musical, logical-mathematical, spatial, naturalistic, bodily-kinesthetic, interpersonal, and intrapersonal. Although he believes that these eight types are interconnected, he also suggests that separate areas 
of the brain are allocated for each type. Applying this theory offers students more learning opportunities.

Multisensory learning occurs when more than one sense is used to retrieve and store information. Such learning is divided into four types: auditory, visual, tactile, and kinesthetic (Suryaratri, Prayitno \& Wuryani, 2019). Multisensory education notes that each child has diverse styles of learning and gives each child the opportunity to succeed under their personal characteristics, presenting the same information from the four above-mentioned approaches.

The learning style theory proposed by Rita and Kenneth Dunn in 1978 is a method of perceiving and processing information in educational situations. Learning styles are defined as general approaches, namely, global, analytical, auditory, and visual. Students use these styles when learning a new language or any other subject. The style used determines the way the student perceives the learning environment and interacts with and responds to it. The learning style could be defined as characteristic cognitive, affective, social, and physiological behaviour, which provides a stable indicator of how students perceive, interact with and respond to the learning environment (Mackeracher, 2004).

There are four main learning styles, represented in Graphic 1: visual, auditory, tactile and kinesthetic.

Figure 1. Learning styles

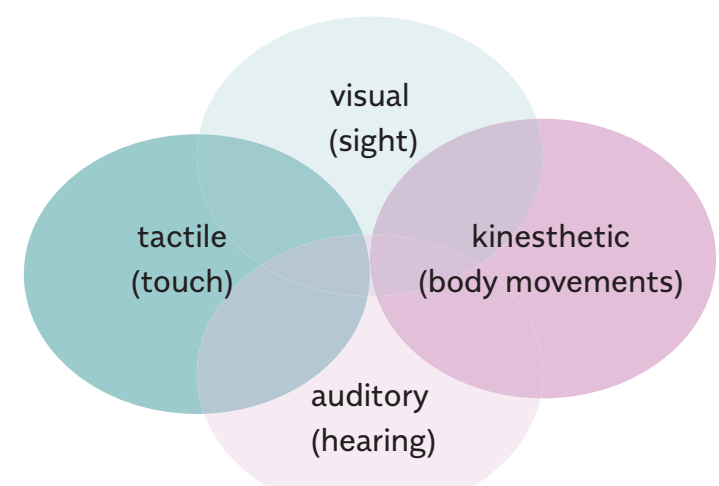


Visual learners

Visual learners think in pictures and learn much better with visual images. They depend on the teacher's non-verbal signals, such as body language. Sometimes visual learners prefer to sit in front, facing their groupmates. They also make descriptive notes on the material presented. Visually-learning children like well-organised material that allows them to find patterns and associate symbols with familiar objects so they can make mental pictures and conserve them in the brain (García \& Sánchez, 2013).

\section{Auditory learners}

These learners discover information by listening to and interpreting information using pitch, emphasis, and speed. They gain knowledge from reading aloud in a group and may not have a complete understanding of written information. The child of this type benefits from music, repeating content, reading aloud, and explaining what they need to other children or their peers (Suryaratri, Prayitno \& Wuryani, 2019).

\section{Kinesthetic learners}

Kinesthetic children learn best with an active and direct approach. These learners prefer interactions with the physical world. Most of the time, kinesthetic learners have difficulty reaching a goal and can lose concentration. Children with kinesthetic types of learning need to move their bodies in order to concentrate and learn. Examples include body movements that indicate a concept or manipulating objects that represent the concepts they are being taught (Gilakjani, 2012).

\section{Tactile learners}

Tactile learners should be able to use their hands, touching all objects around them. It is important for them to have information about the texture, temperature, consistency or even weight of the object of study in order for them to keep and understand the information deeply. These learners enjoy having different sensorial experiences; they notice the varied materials of clothes, for example, and the touched experience lets them predict the quality of an object (García \& Sánchez, 2013). 


\section{Multisensory teaching}

Multisensory teaching means using a technique that permits the child to learn through more than one sense. Common techniques are teaching through sight or hearing (visual or auditory). The child used sight for looking at text and pictures or reading information on the board. Hearing is used to listen to what the teacher says. Difficulties with tracking or visual processing may affect the child's vision.

Sometimes, the child's auditory processing may be weak. The solution to this difficulty is to involve the use of more senses, e.g. the use of images (visual), touch (tactile) or movement (kinesthetic). This will help the brain develop tactile and kinesthetic memories to hang on to, as well as auditory and visual ones.

Students with learning difficulties often struggle in the areas of reading, spelling, writing, listening comprehension and expressive language. Multisensory techniques enable students to use their personal areas of strength to help them learn. They can range from simple to complex, depending on the needs of the student and the task at hand. The multisensory approach can be applied to young children, children with special needs, and learners with dyslexia or disabilities (Fister, Stevenson, Nidiffer, Barnett \& Wallace, 2016).

In the classroom, most children understand the material better when more than one method is used. For example, when children learn about oranges, the teacher first talks about and explains the characteristics of oranges and how they grow. Later, the children can inspect, touch, smell and taste oranges, and they can also divide into two groups and count the number of seeds so they will have diverse experiences of one concept. In multisensory instruction, children convey information through such things as touch, movement, vision and hearing. Table 1 presents some examples of techniques that can stimulate each sense. 
Table 1. Multisensory Techniques

\begin{tabular}{|c|c|}
\hline VISUAL TECHNIQUES & AUDITORY TECHNIQUES \\
\hline $\begin{aligned} \rightarrow & \text { Text, pictures, posters, toys, } \\
& \text { projection screens, computers, } \\
& \text { flashcards } \\
\rightarrow & \text { Use of color for highlighting and } \\
& \text { organising information or imagery } \\
\rightarrow & \text { Graphic organizers, } \\
& \text { outlining passages } \\
\rightarrow & \text { Student-created art, images, videos } \\
\rightarrow & \text { Real objects }\end{aligned}$ & $\begin{array}{l}\rightarrow \text { Recordings } \\
\rightarrow \text { Poems } \\
\rightarrow \text { Music and songs } \\
\rightarrow \text { Reading a story (Storytime) }\end{array}$ \\
\hline $\begin{aligned} & \text { TACTILE TECHNIQUES } \\
& \rightarrow \text { Use of toys } \\
& \rightarrow \text { Use of textures (sand, finger paint, } \\
& \text { different papers, pastes) } \\
& \rightarrow \text { Modeling materials (clay } \\
& \text { and sculpting materials) } \\
& \rightarrow \text { Experiences of touching real objects }\end{aligned}$ & $\begin{aligned} & \text { KINESTHETIC TECHNIQUES } \\
& \rightarrow \text { Action games involving moving } \\
& \text { the body, arms, legs, head, etc. } \\
& \rightarrow \text { Dancing to songs } \\
& \text { related to the concepts }\end{aligned}$ \\
\hline
\end{tabular}

The multisensory method of teaching English as a second language is effective because children associate the second language with the perceptions and sensations they experience. This is a form of instruction that improves children's learning because it is based on meaningful and experiential learning. Education is perceived as a constructive and responsive process in which children play an active role.

The multisensory approach has been used in different countries for teaching English as a second language, and, through a comparison of test results, has been shown to be more effective than the traditional method in a case study in Jordanian schools. In 2012, Sereen Jubran concluded that students were more engaged in learning when they were given a chance to use all their senses. Furthermore, she added, using a multisensory approach is a powerful tool (Jubran, 2012).

Sanchez and Garcia (2013) created a programme in a kindergarten using a multisensory approach in teaching a second language to younger preschoolers, based on the Visual-Auditory-Kinesthetic model. They found that the learning process is conceived naturally and spontaneously; this model allows a teacher and a child to work 
on different topics and contexts, creating an ideal environment for the meaningful acquisition of the language.

In Russia, the use of the method is described by some authors, e.g. Voloshko (2014), who combined the multisensory approach with the tandem method in an international group with Russian and British preschoolers aged from 4 to 6 years in a summer camp. During this time, pictures and bilingual presentations were used, and cinema time with cartoons in Russian and English was also organised. In addition, there were creative activities (fairy tales and poems) relating to Russian and British culture, traditions and customs. At the end of the course, the preschoolers staged fairytales in Russian and English. The result was that the use of the multisensory approach helped to involve students in communication and made the learning process more accessible and effective.

\section{Conclusion}

In the modern world, knowledge of a second language is becoming a necessity. But how to learn and how to teach a second language is still being studied by experts. Over the years, specialised methods have developed. These often use songs, videos, poems and repetition games, and many also include body movements, such as the TPR method, which involves a person in actions beyond hearing and verbal repetition.

With children, the use of the game as a teaching method is vital, because with the help of this activity the child develops holistically, and if this activity is used by the teacher for a specific purpose, the child receives this information pleasantly and feels more connected to the process of participating and learning. Using technology in education is a tool that cannot be ignored; it is a useful way in which children can learn in a fun manner, but it should be utilised as an oriented tool and for a planned purpose. A language is learnt and improved with human interaction, not just with machines.

Language comprises four main areas - speaking, listening, reading and writing - and these are developed by children with their families and in the school environment. However, when teaching a second language, the teacher should plan actions that allow their students to improve in each of these areas.

The best way to learn a second language is still an open question. The various methods and techniques are still being researched. Among 
these techniques is the multisensory approach, which aims at supplying information by stimulating various sensory paths so that the brain can assimilate it efficiently.

The framework of the multisensory approach implies that children study and assimilate information in diverse ways: considering the theory of multiple intelligence, each child has the mental and physical capabilities for more productive work in various fields of knowledge. The multisensory method has been used in kindergarten for various purposes, and it has also been used to help children with learning difficulties. It has proved to be effective, and its principles are used in other methods (Montessori, cited in: Tello Puente, 2017). It is intended for children to study the environment using all their senses.

The uses of different methods for teaching second languages at the preschool age have been studied to consider how a child can be connected with a new language in a more effective way. It can be stressful for a child to be in the environment with a language that is not used in their daily life, in which case the teacher should connect the child with the language in a way that motivates them to learn new vocabulary and easily relate it to the concepts that they already know from their mother tongue. Using the multisensory method in teaching second languages allows the child to learn a new language, similar to learning their native language, as it allows them to be involved in the new vocabulary through doing different activities as well as receive information from various communication channels (visual, auditory, kinesthetic, tactile), allowing the brain to memorize and store information effectively. More research still needs to be done in order to further our understanding of the issues.

\section{References}

$\rightarrow$ Ageeva, A. V. (2018). The Relevance of Teaching English to Preschoolers and The Corresponding Difficulties in The Work of Teachers [in Russian]. In: National Priorities of Modern Russian Education: Problems And Prospects (pp. 94-98), https://Elibrary.Ru/Item.Asp?Id=36696409

$\rightarrow$ Alvarez, M. V. (2010). El Inglés Mejor A Edades Tempranas, Pedagogía Magna, 5, 251-256.

$\rightarrow$ Asher, J. J. (1966). The Learning Strategy of The Total Physical Response: A Review, The Modern Language Journal, 50(2), 79-84. 
$\rightarrow$ Balashova, V. V. (2016). Multi-Touch Technology in English Classes [in Russian]. Paper presented at the Modern Forms Of Organization Of Educational Activities conference. Moscow Region, Serpukhov, www.pedopyt.ru/conference_notes/7.

$\rightarrow$ Birchenall, L. B. and Müller, O. (2014). La teoría lingüística de Noam Chomsky: del inicio a la actualidad, Lenguaje, 42(2), 417-442.

$\rightarrow$ Canga, A. A. (2019). El Método De La Respuesta Física (Tpr) Como Recurso Didáctico Para El Aprendizaje Del Inglés En Educación Infantil, Revista Iberoamericana De Educación, 60(3).

$\rightarrow$ Cañas, L. Á. and Chacón, C. T. (2015). Aportes De La Neurociencia Para El Desarrollo De Estrategias De Enseñanza Del Inglés, Acción Pedagógica, 24(1), 52-61.

$\rightarrow$ Chakhchakhova, E. A., Tolstykh, V.V. and Ansimova, K. A. (2016). Development of Children's Creative Activity in English Lessons [in Russian]. In: Actual Problems of Pedagogy: Materials of the VII international conference (pp. 14-17).

$\rightarrow$ Diez, V. Á. (2010), El Inglés Mejor a Edades Tempranas, Pedagogía Magna, 5, 251-256.

$\rightarrow$ Dunn, R. and Dunn, K. (1978). Teaching students through their individual learning styles: A practical approach. Reston: Prentice Hall.

$\rightarrow$ Fister, J. K., Stevenson, R. A., Nidiffer, A. R., Barnett, Z. P., Wallace, M. T. (2016). Stimulus Intensity Modulates Multisensory Temporal Processing, Neuropsychologia, 88, 92-100.

$\rightarrow$ García Marulanda, K. and Sánchez, V. A. (2013). El Taller De Inglés: Un Acercamiento Significativo Al Aprendizaje De Una Lengua Extranjera Fundamentado En El Modelo Visual-Auditivo-Kinestésico En Niños De 4 Años De Una Institución Privada, http://ridum.umanizales.edu.co:8080/jspui/handle/6789/895

$\rightarrow$ Gardner H. (1993), Frames of Mind: The Theory of Multiple Intelligences. New York: Basic Books.

$\rightarrow$ Ghaffari, M., Kashkouli, S. M. and Sadighi, F. (2017). Montessori And Conventional Teaching Methods In Learning English As A Second/Foreign Language: An Overview, Journal of Applied Linguistics and Language Research, 4(5), 209-218.

$\rightarrow$ Ghoneim, N. M. M. and Elghotmy, H. E. A. (2015). The Effect of a Suggested Multisensory Phonics Program on Developing Kindergarten Pre-Service Teachers' Efl Reading Accuracy and Phonemic Awareness, English Language Teaching, 8(12), 124-143.

$\rightarrow$ Gilakjani, A.P. (2012). Visual, Auditory, Kinaesthetic Learning Styles and Their Impacts on English Language Teaching, Journal of Studies in Education, 2(1), 104-113. 
$\rightarrow$ Hernández, V. (2016). Fonética En Ele: Los Elementos Suprasegmentales Y Su Aplicación En El Aula, Doctoral dissertation, Universidad de Oviedo, http://hdl. handle.net/10651/37647

$\rightarrow$ Jensen, E. (ed.) (2004). Brain-Compatible Strategies. Thousand Oaks, CA: Corwin Press.

$\rightarrow$ Jubran, S. (2012). Using Multi Sensory Approach for Teaching English Skills And Its Effect On Students' achievement at Jordanian Schools, European Scientific Journal, 8(22).

$\rightarrow$ Koryakovtseva, O. V. (2010). Methods of teaching English to pre-school children, Doctoral dissertation. Moscow: Moscow State Linguistic University.

$\rightarrow$ Krashen, S. D., Kerrell, T. D. (1983). The natural approach: language acquisition in the classroom. Oxford: Pergamon.

$\rightarrow$ Lněničková, I. and Chocholatá, M.J. (2015). Montessori Language Teaching: Materials Analysis and Evaluation, Master's thesis. Brno: Masaryk University, Https://ls.Muni.Cz/Th/166802/Pedf_M/Diplomova_Prace_Lnenickova_Aeh7l.Pdf

$\rightarrow$ Lomakina, G.R. and Laer, A.A. (2014). Early Learning of a Foreign Language: Pros and Cons, Young Scientist, 20, 597-599.

$\rightarrow$ López Maján, A. (2018). La Enseñanza Y Aprendizaje De Una Segunda Lengua En Educación Infantil: El Caso Del Español, Http://Uvadoc.Uva.Es/ Bitstream/10324/31644/1/Tfg-O-1325.Pdf

$\rightarrow$ Lucci, M. A. (2011). La propuesta de Vygotsky: la psicología socio-histórica, Profesorado. Revista de currículum y formación del profesorad, 10(2), 1-11.

$\rightarrow$ Mackeracher, D. (2004). Making Sense of Adult Learning. Toronto: University of Toronto Press.

$\rightarrow$ Martin, K. (2017). The Impact of Song And Movement on Kindergarten Sight Word Acquisition, https://rdw.rowan.edu/etd/2489/

$\rightarrow$ Medina, M., Melo, G. and Palacios, M. (2013). La importancia del aprendizaje del idioma inglés a temprana edad, Yachana Revista Científica, 2(2).

$\rightarrow$ Milrud, R. P. (2014). Teaching English In Preschool Education: The Experiment Continues, Education - Foreign Languages, 11, 34-46.

$\rightarrow$ Montessori, M. and Bofill, M. (1986). La mente absorbente del niño. México: Diana.

$\rightarrow$ Montessori, M. and Vera, P. (1918). El método de la pedagogía científica: aplicado a la educación de la infancia. (No. 371.4 Montessori). Barcelona: Casa Editorial Araluce.

$\rightarrow$ Oyarbide, M. A. (2004). Jerome Seymour Bruner: de la percepción al lenguaje, Revista Iberoamericana de Educación, 34(1), 1-19.

$\rightarrow$ Piaget, J. (1981). La teoría de Piaget, Infancia y aprendizaje, 4(sup2), 13-54. 
$\rightarrow$ Polo Torres, M. L. (2005). Bilingüismo en la edad preescolar, Bachelor's thesis. Universidad del Azuay, http://dspace.uazuay.edu.ec/bitstream/ datos/728/1/05137.pdf

$\rightarrow$ Richards, J. C. and Rodgers, T. S. (2014). Approaches and methods in language teaching. Cambridge: Cambridge University Press.

$\rightarrow$ Sánchez, M. Á. M. (2010). Aproximación histórica a la enseñanza de lenguas extranjeras, Aula, 16, 137-154.

$\rightarrow$ Setyarini, S., Soleimani, H. and Akbari, M. (2011). Storytelling: An innovative language learning for English young learners, http://a-research.upi.edu/ operator/upload/pros_ui-itm_2011_setyarini_innovative_language_learning. pdf

$\rightarrow$ Sholpo, I. L. (1999). How to teach a preschooler to speak English: A textbook on the method of teaching English for pedagogical universities, colleges and colleges in the specialty "Teacher of a foreign language in kindergarten" [in Russian]. St. Petersburg: Special literature.

$\rightarrow$ Skinner, B. F. (1957). Verbal Behavior. New York: Appleton-Century-Crofts.

$\rightarrow$ Suryaratri, R. D., Prayitno, E.H. and Wuryani, W.(2019). The Implementation of Multi-Sensory Learning at Elementary Schools in Jakarta, Jurnal Pendidikan Usia Dini, 13(1), 100-113.

$\rightarrow$ Tkachenko, A. S. (2016). Features of Teaching English To Preschool Children, Youth Scientific Forum: Humanities, 11, 167-170.

$\rightarrow$ Tello Puente, M. A. (2017). Método Montessori En El Proceso De Enseñanza Aprendizaje En El Idioma Inglés, En Los Estudiantes De Inicial 2, En La Escuela Albany Junior School, Bachelor's thesis. Universidad Central Del Ecuador, www.Dspace.Uce.Edu.Ec/Handle/25000/11108

$\rightarrow$ Voloshko, M. O. (2014). Multisensory Approach in Teaching English To Children Of Preschool And Primary School Age In The Framework of A Collective Tandem Course [in Russian]. Innovative future of Pedagogy and psychology: collection of articles. Collected papers International scientific and practical conference. Ufa: Aeterna Research Center, https://elibrary.ru/download/ elibrary_22541759_59833657.pdf.

$\rightarrow$ Vorobyova, O. I. (2011). Methodological aspects of teaching English in preschool institutions [in Russian], https://lib.vsu.by/xmlui/handle/123456789/4573 